\title{
36. THE PALEOCEANOGRAPHIC HISTORY OF THE NORTH ATLANTIC-ARCTIC GATEWAYS: SYNTHESIS OF THE LEG 151 DRILLING RESULTS ${ }^{1}$
}

\author{
Jörn Thiede² and Annik M. Myhre ${ }^{3}$
}

\begin{abstract}
During Leg 151, seven locations were drilled in the western Norwegian-Greenland Sea, in Fram Strait, and on the Yermak Plateau. These sites allow us to address the paleoceanographic and climatic history of the surface- and bottom-water masses in high Northern Hemisphere deep-sea basins, of the mode and pattern of water exchange between the Arctic Ocean and the Norwegian-Greenland Sea through Fram Strait, and the Neogene and Quaternary history of glaciation of the surrounding shelves and land regions. A detailed and well-developed pelagic biochronology has been defined for all of the sites, allowing correlation of their stratigraphic record to sedimentary sequences from lower latitudes. Except for a few short-lived interruptions caused by hiatuses, the entire paleoceanographic history from the Eocene, when the Norwegian-Greenland Sea was small and narrow, to the Quaternary can be described.

When the Norwegian-Greenland Sea was small and consisted of a sequence of narrow basins, surface water penetrated the area from the North Atlantic Ocean and brought temperate to subtropical siliceous faunas and floras. Only during the latter part of the Oligocene and the early part of the Miocene did cool to temperate water develop. The first signs of marine ice covers or the presence of icebergs developed during the late Miocene, earlier on the Iceland Plateau, later in the northern and eastern part of the investigated region. The influence of the marine ice covers and of the influx of icebergs, first from Greenland and later from northwestern Europe, increased during the course of the Pliocene until it reached an important threshold approximately 3 to $4 \mathrm{Ma}$ off southern Greenland and only $2.6 \mathrm{Ma}$ in Fram Strait and off northwestern Europe. This is interpreted as an increase in the dynamics and growth of the ice caps on either side of the Norwegian-Greenland Sea.

In the course of the Pliocene and Quaternary, rapid changes between glacials and interglacials can be observed. Some of the sediment properties reflect Milankovitch frequencies: in the earlier part of the history these were mainly obliquity-related; during the past 600-700 k.y. that were mainly eccentricity-related. A temperate interval in the middle Pliocene interrupted the history of the delivery of ice-rafting even in Fram Strait and coincided well with the development of boreal forests on northeastern Greenland. Site 907 on the central Iceland Plateau received large quantities of volcanic ash related to the volcanism developed on Iceland and potentially also on Jan Mayen. Site 908 on the Hovgård Ridge allows us to address the tectonic history of the opening of Fram Strait and of the subsidence of the Hovgård "microcontinent." The drill sites of the Yermak Plateau are heavily influenced by sediments related to the development of glaciation on Svalbard. Site 910 penetrated a clearly overconsolidated part of the sequence and seems to have been overridden by the Svalbard ice cap, prior to $\sim 600 \mathrm{ka}$.
\end{abstract}

\section{INTRODUCTION: SCOPE OF THE PALEOCEANOGRAPHIC SYNTHESIS}

The Norwegian-Greenland Sea and the gateways to the North Atlantic Ocean, as well as to the Arctic Ocean, are young geological features. However, these features had an important impact on the oceanographic properties of the world ocean. Their formation generated passages for the deep-water exchange between the Northern and Southern Hemispheres. Because of its importance, this area has been visited repeatedly by the Ocean Drilling Program to study its paleoceanographic history. ODP Leg 104 addressed the evolution and variability of the Norwegian Current in the eastern part of the Norwegian-Greenland Sea (Eldholm, Thiede, Taylor, et al., 1987, 1989), whereas it was left to the North Atlantic-Arctic Gateway Program of ODP to study the southern gateway in considerable detail in the western and northern part of the entire system (Fig. 1). In this chapter we synthesize the paleoceanographic aspects of the drilling results of ODP Leg 151 (Fig. 2), which took place in late summer 1993 as the

'Thiede, J., Myhre, A.M., Firth, J.V., Johnson, G.L., and Ruddiman, W.F. (Eds.), 1996. Proc. ODP, Sci. Results, 151: College Station, TX (Ocean Drilling Program).

${ }^{2}$ GEOMAR, Research Center for Marine Geosciences, Wischhofstraße 1-3, D24148 Kiel, Federal Republic of Germany. jthiede@ geomar.de

'Department of Geology, University of Oslo, Postbox 1047. Blindern, N-0316 Oslo 3 , Norway. first part of the North Atlantic-Arctic Gateway Program. ODP Leg 162 (Jansen, Raymo, Blum, et al., 1996) drilled in the southern part of the investigated area, namely on both sides of the Greenland-Scotland Ridge, but it also visited the northern Norwegian-Greenland Sea to drill one of the glacial trough mouth fans to the west off Svalbard (Fig. 3). Leg 151 allows us to address the western part of the Norwegian-Greenland Sea, in particular Fram Strait and the depositional environment of the adjacent part of the Arctic Ocean on Yermak Plateau (Fig. 4). The results of Legs 104 (Eldholm, Thiede, Taylor, et al., 1989), 151 (Myhre, Thiede, Firth, et al., 1995), and 162 (Jansen, Raymo, Blum, et al., 1996) therefore have to be seen in conjunction. In this volume we are trying to present mainly the drilling results of Leg 151 ; however, brief reference will be made to the drilling results of the other ODP legs.

The main aim is to extract from the various special chapters the information on the paleoenvironmental history of the individual drill sites and to try to establish a paleoceanographic synthesis of the area, in particular of the northern gateway between the Arctic Ocean and Norwegian-Greenland Sea. We will go through several steps to establish this synthesis, mainly by describing the drilling records from the individual drill sites and by establishing the stratigraphic framework of the individual parts of the lithologic sequences. We will also use information on the volcanic history of the area and of the tectonic evolution to identify the paleoceanographic response to this endogenically driven part of the history of the area.

The sedimentary sequences that were recovered from the Leg 151 drill sites are dominantly terrigenous sediment components with mi- 


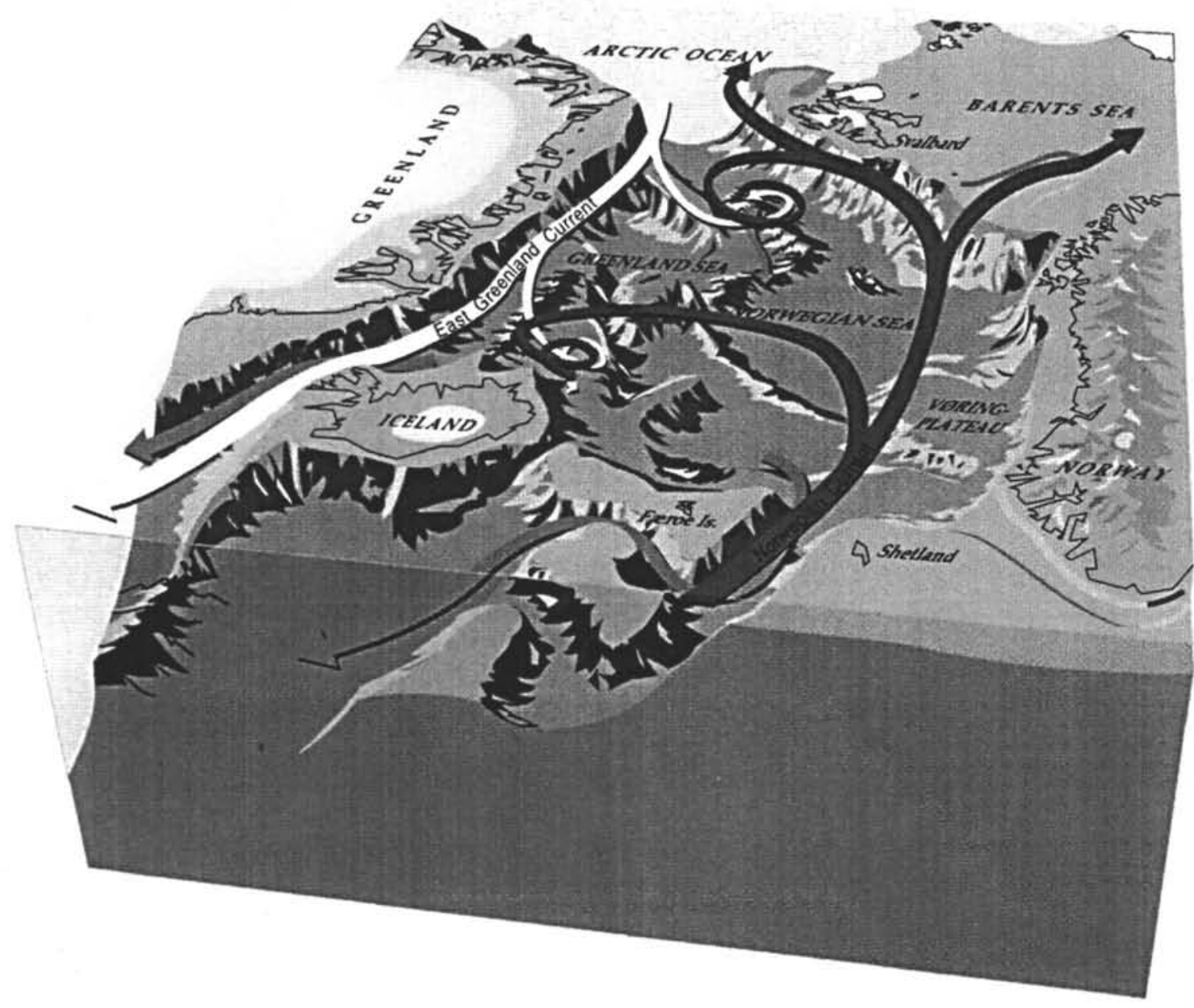

Figure 1. Physiographic diagram of the Norwegian-Greenland Sea, including the gateways from the North Atlantic Ocean into the Norwegian Greenland Sea (Greenland Scotland Ridge) and from the Norwegian Greenland Sea into the Arctic Ocean (Fram Strait). The current systems and their patterns of advection are shown schematically only, but this illustrates vividly how important the Norwegian-Greenland Sea is for shallow- and deep-water exchange of the major oceanic water masses in the North Atlantic Ocean. (Computer graphics by Masaocki Adachi, Department of Geology, University of Bergen/Norway).

nor biogenic planktonic and benthic remains. These components and remains contribute to an understanding of the depositional environment by means of their occurrence and stratigraphic distribution, their state of preservation, and their relationships. The Leg 151 drill sites cover the entire range of depositional environments from preglacial times when the Norwegian-Greenland Sea was a rather small ocean basin filled by temperate to subtropical surface waters (Vogt et al., 1981), until the late Cenozoic, when the Norwegian-Greenland Sea was repeatedly and frequently affected by major glaciation events. Thus, we are able to document almost completely the exciting revolution of a segment of the Northern Hemisphere that is particularly interesting for the habitants of northwestern Europe. Finally, we will use the information and interpretation of the Leg 151 record to identify a number of open questions that should be pursued by means of paleoceanographic studies.

\section{Main Drilling Results of Leg 151}

As shown in Figure 2, the locations visited during Leg 151 spread over a range of different depositional environments (Myhre and Thiede, 1995). The drilling results will be described in sequential order from South to North. Site 907 is located in the pelagic environment of the Iceland Plateau on oceanic crust of questionable age (cf.
Davis and McIntosh, this volume). Site 913 sampled the deep Greenland Basin off the East Greenland continental margin on potentially very old oceanic crust; the locality was situated for most of the time under water masses of the open and deep Greenland Basin. However, today it is close to the eastern boundary of the East Greenland Current. Sites 908 and 909 must be considered as a pair, as they sampled the deep and shallow depositional environments of Fram Strait, which comprises the sill between the deep Arctic Ocean and the NorwegianGreenland Sea. Finally, Sites 910,911, and 912 all sample young sections on the Yermak Plateau located close to the present ice edge (cf. fig. 14 in Thiede and Myhre, chapter 1, this volume) and they document the young depositional history of the marginal Arctic Ocean. A comprehensive documentation of the drill site locations and of the drilling records can be found in the Initial Reports of Leg 151 (Myhre, Thiede, Firth, et al., 1995). The original lithologic records that were obtained during Leg 151, and their subdivision into lithologic units, are shown in Figure 2B.

\section{Site 907}

Site 907 on the eastern Iceland Plateau was cored to 224.1 mbsf and encountered basalt in the lower $7.8 \mathrm{~m}$. The upper $16.8 \mathrm{~m}$ of the sedimentary column consists of bioturbated Quaternary clayey silts, 


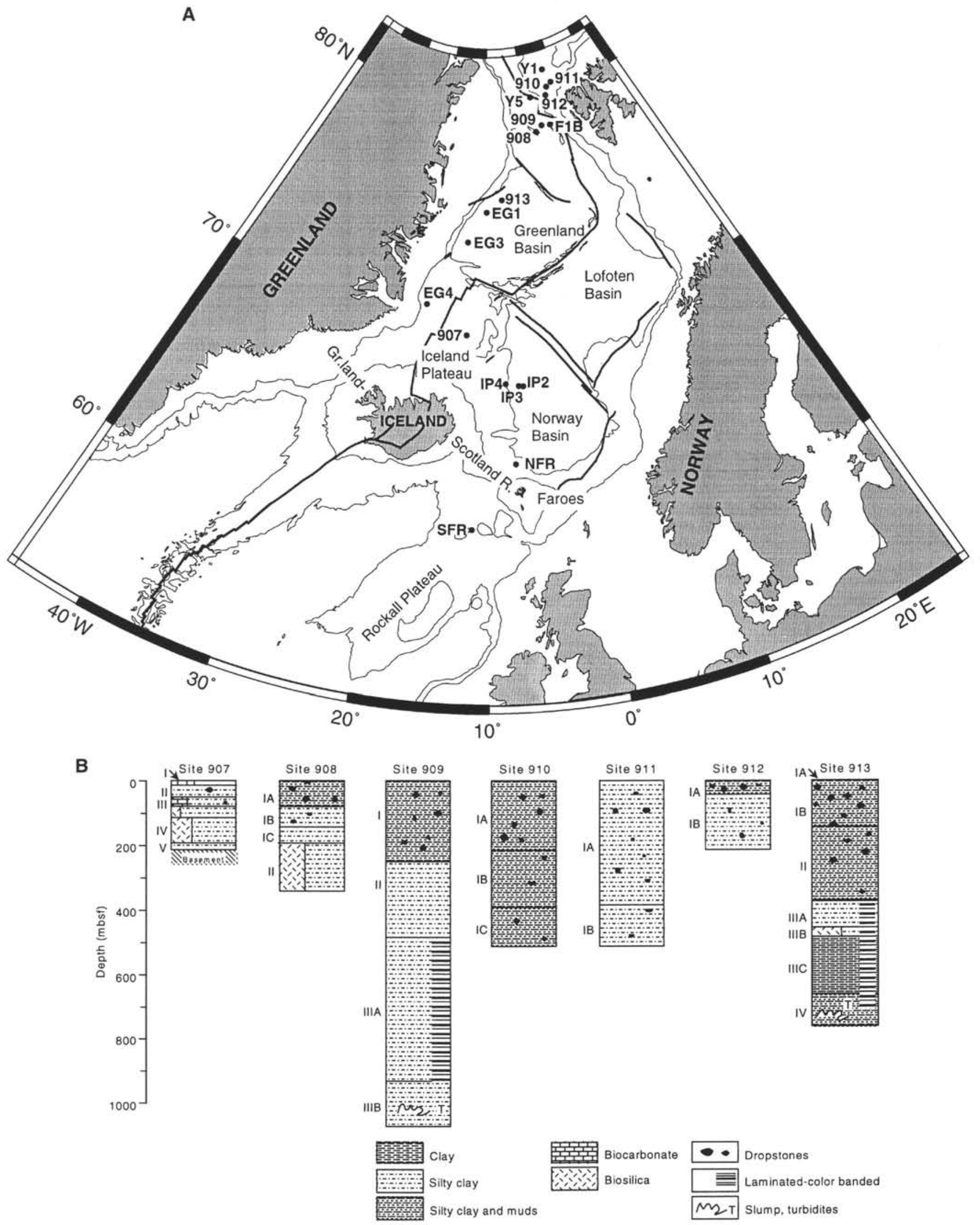

Figure 2. A. Location map of Leg 151 drill sites, as well as previous ODP and DSDP drilling in the Norwegian Greenland Sea. GFZ = Greenland Fracture Zone, $\mathrm{GE}=$ Greenland Escarpment, $\mathrm{SFZ}=$ Spitsbergen Fracture Zone, VE = Vøring Escarpment, JMFZ = Jan Mayen Fracture Zone, FSE $=$ Faeroe Shetland Escarpment. B. Lithologic records from the Leg 151 drill sites (from Myhre, Thiede, Firth, et al., 1995). 


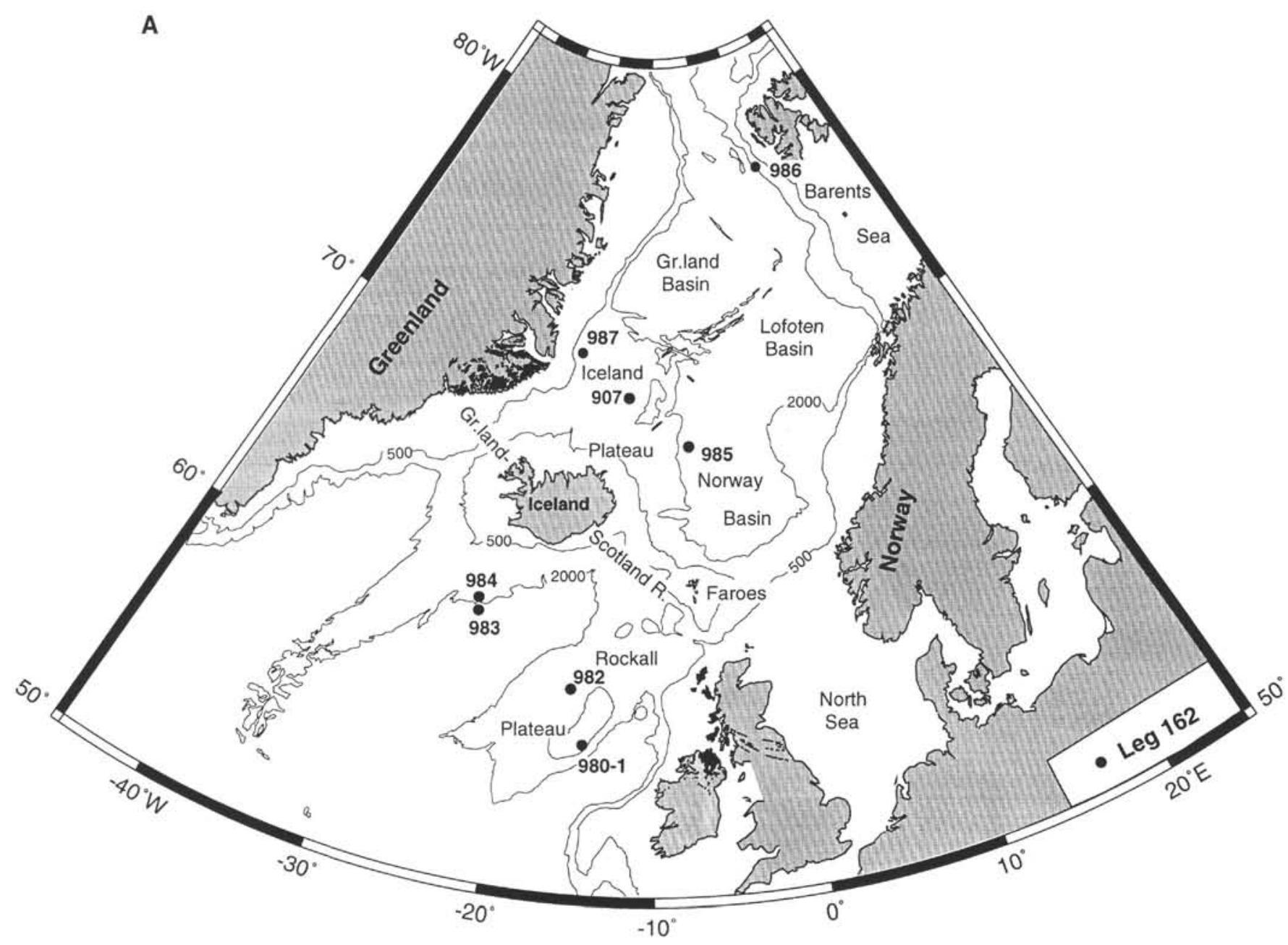

Figure 3. A. Location map of Leg 162 drill sites. B. Lithologic columns of the Leg 162 drill sites (both from Jansen, Raymo, Blum, et al., 1996).

silty clays, and foraminifer-bearing silty muds with minor amounts of biosilica, as well as small inclusions of silty carbonate ooze. Dropstones or ice-rafted debris (IRD) $>1 \mathrm{~cm}$ are rare. Pliocene to Quaternary massive clayey silts and silty clays were found at the interval 16.8 to $56.3 \mathrm{mbsf}$, with virtually no biogenic carbonate and only rare volcanic glass. Unit III (56.3-18.1 mbsf) consists of bioturbated upper Miocene to Pliocene clayey silts and silty clays with biogenic silica with a clear increase in volcanic glass content and a decrease in quartz and feldspar downcore. IRD is found throughout in small quantities. In the upper part, a few layers of interbedded nannofossil ooze and nannofossil silty clay are observed that are absent in the lower part. The interval 118.1 to $197.3 \mathrm{mbsf}$ consists of bioturbated middle to upper Miocene ash- and biosilica-bearing silty clays and clayey silts with greenish-gray color bands throughout the unit. Ash layers are common in the upper part and have been analyzed in great detail by Lacasse et al. (this volume) and Werner et al. (this volume), both to determine the source area. The underlying 197.3 to 216.3 mbsf consists of bioturbated middle Miocene clayey mud and silty clay which has high quartz and clay contents and low biosilica. Volcanic glass commonly fills burrows. The sedimentary sequence rests on top of acoustic basement which seems to consist of pillow basalts (cf. Davis and McIntosh, this volume). Physical property measurements and shipboard logging established the cyclic nature of many lithologic parameters of the sedimentary column (cf. Rack et al, this volume).

\section{Site 913}

Site 913 (deep Greenland Basin) is located on some of the oldest Norwegian-Greenland Sea crust (magnetic Chron C24N.3N, approximately $53 \mathrm{Ma}$, according to Berggren et al., 1995) and was cored to $770.3 \mathrm{mbsf}$. Because of the very high abundance of large dropstones, as well as gravel and sandy layers, the upper $423 \mathrm{mbsf}$ suffers from poor recovery. The upper $307.2 \mathrm{mbsf}$ is in large part glacially influenced. It consists of massive interbedded lithologies that have a variety of textures from clay to silty clay and clayey mud to silty sand with common gravel and sandy layers, $2 \%$ to $6 \%$ carbonate and $0.1 \%$ to $1 \%$ organic carbon. Dropstones are particularly prevalent in the upper $131 \mathrm{mbsf}$ and include sedimentary, igneous, and metamorphic lithologies. Crystalline rocks are predominant. Siliciclastics dominate the shallow sediments, but planktonic and benthic foraminifers compose up to $40 \%$ of specific layers, and nannofossils are a trace component. The siliciclastics are still present in sediments recovered from below 435 mbsf but are not dominant. Particularly interesting are sediments from the interval 462 to 503 mbsf of late Eocene to early Oligocene age which contain biosilica-bearing clay, biosiliceous clay to silty clay, and clay and silty siliceous ooze layers of dusty to bright greens, blues, and purples. Diatoms and radiolarians both occur in concentrations as great as $20 \%$. Farther below the sediments are laminated silty clays and massive silty clays as well as clayey silty muds with fining-upward sequences. Drilling ended in the lowermost 


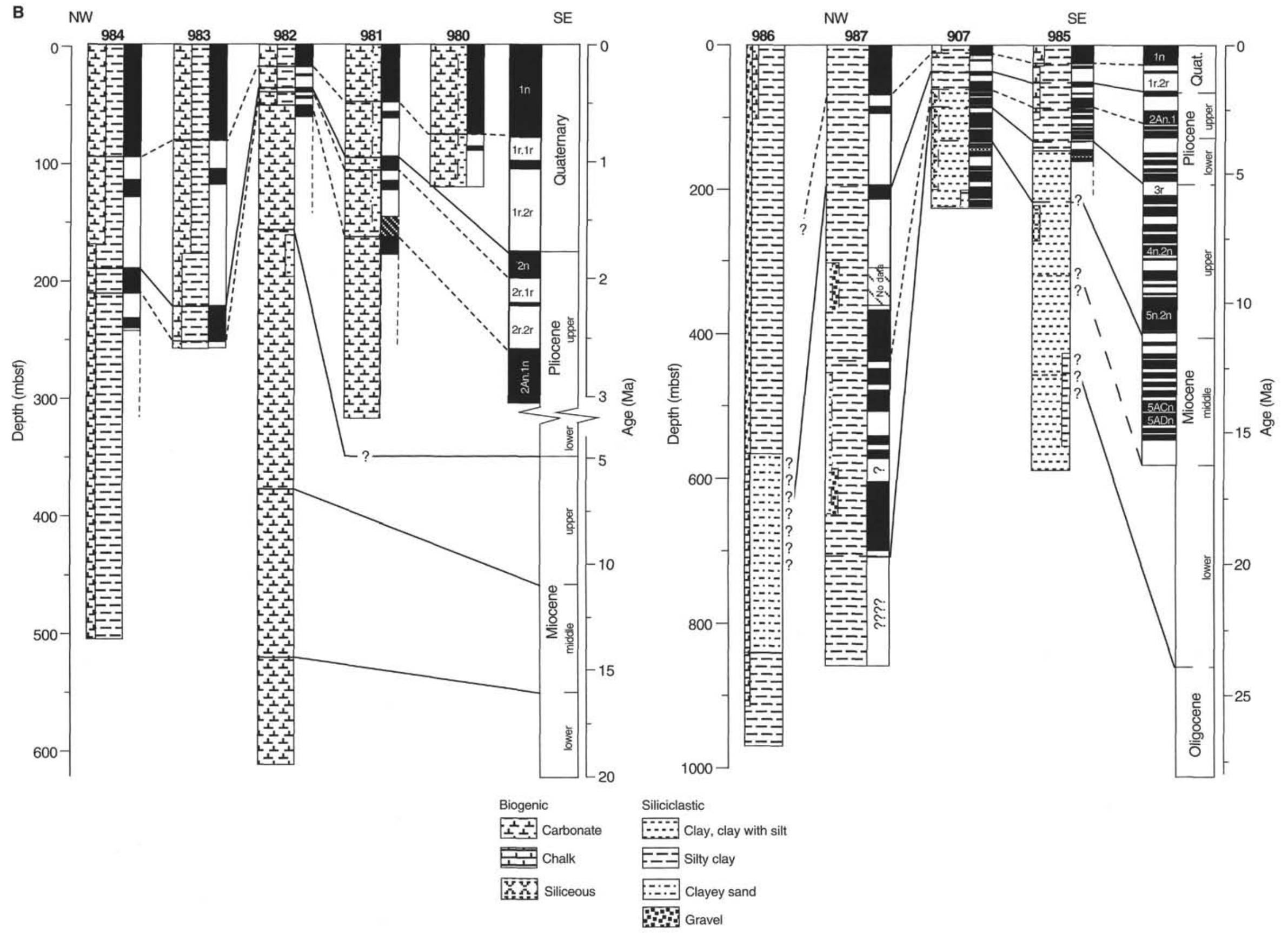




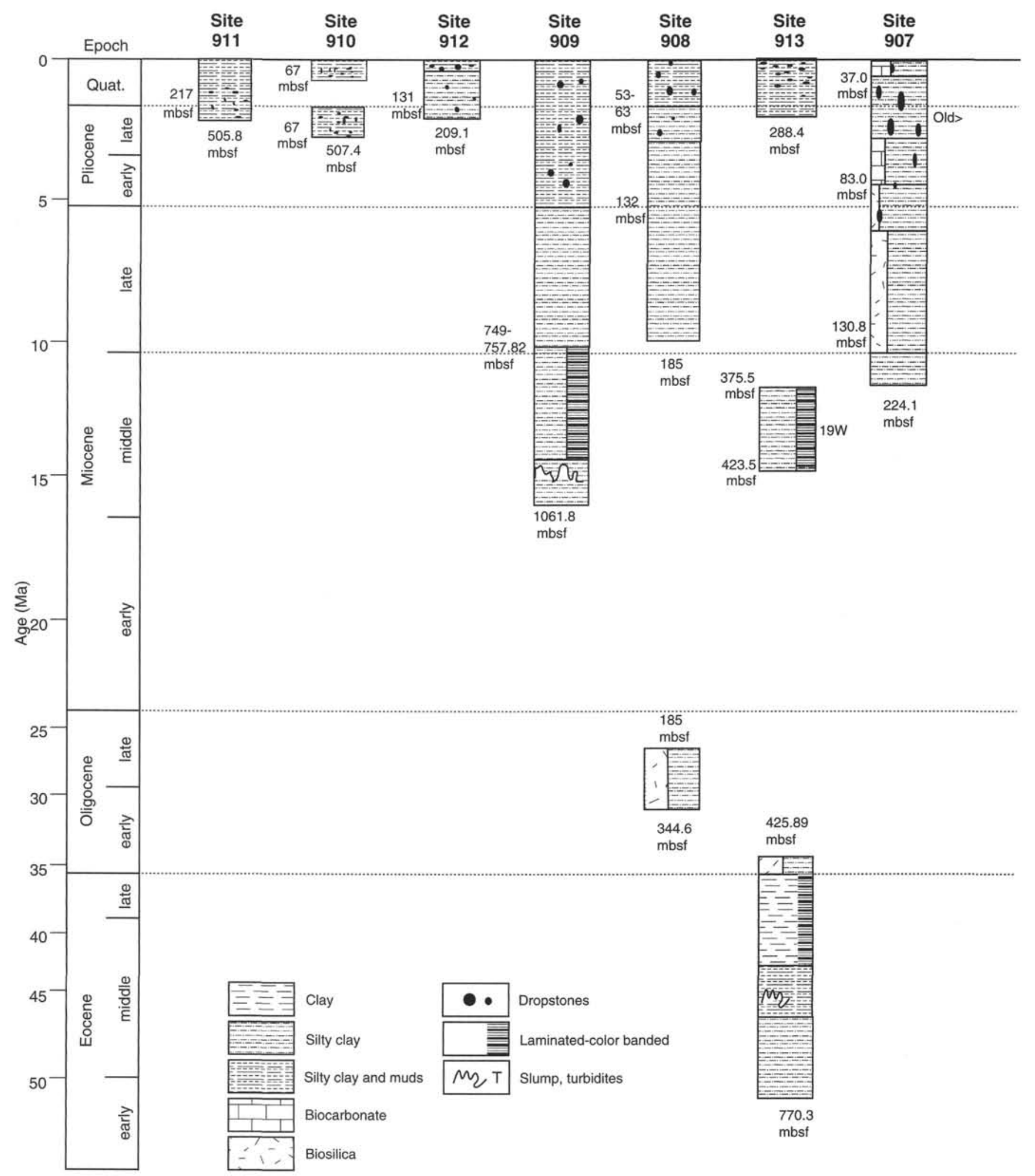

Figure 4. Lithologies and ages of sediments recovered at Sites 907 through 913 (revised after Thiede et al., 1995). 
part because of some layers of well-cemented calcareous sand- and siltstones. Sediments and their ages are described in detail in Myhre, Thiede, Firth, et al. (1995).

\section{Sites 908 and 909}

Site 908 is located on the Hovgård Ridge in only $1243 \mathrm{~m}$ of water, whereas Site 909 was drilled through an undisturbed horizontally stratified sequence of sediments close to the deepest part of Fram Strait in approximately $2.5 \mathrm{~km}$ of water. Sediments from both locations are dominantly terrigenous in origin but because of the big difference in water depths, their compositions display considerable differences.

At Site 908, upper Miocene to Quaternary deposits are found in the interval 0 to $185 \mathrm{mbsf}$. They consist entirely of clayey and silty muds to silty clay except for a few intervals with foraminifer-bearing clay or silty mud in the uppermost cores and some distinctive ash layers. The dropstone concentrations in this uppermost unit (mainly clastic sedimentary rocks) fluctuate considerably. They reflect a dominantly glacial depositional regime with rare appearances of gla$\mathrm{cial} /$ interglacial faunas and floras. It is particularly interesting to note that the entire section is very rich in terrestrial organic material. The underlying sediments (185 to $344.6 \mathrm{mbsf}$ of late/early to early/late Oligocene age) consist of bioturbated biosilica-rich, silty clays with abundant diatoms and common radiolarians and sponge spicules. Based on the seismic reflection profile BU81-24 (cf. Myhre, Thiede, Firth, et al., 1995), an angular unconformity of late Miocene age can be observed separating the two units.

The deep Site 909 penetrated relatively fine-grained sediments. In the uppermost interval 0 to $248.8 \mathrm{mbsf}$, Pliocene to Quaternary deposits consist of color-banded, interbedded clays and clayey muds with varying amounts of IRD (down to $240 \mathrm{mbsf}$ ). Dropstones are mostly clastic sedimentary and crystalline rocks, rarely limestones. Very obvious are frequent coal fragments in many horizons. In the upper $50 \mathrm{~m}$ minor occurrences of calcareous nannofossils have been observed. The interval 248.8 to 518.3 mbsf consists of variably bioturbated and color-banded silty clays and clayey silts, increasingly fissile downhole, and contains common pyrite. Some clays are carbonate rich. In the interval 518 to $1061.8 \mathrm{mbsf}$, dark gray silty clays and clayey silts and muds, sometimes carbonate-bearing, have been encountered. There are clearly developed alterations of bioturbated and laminated layers (on a meter scale). The lowermost sediments comprise dark gray silty clays, clayey silts, and silty muds that have several intervals of folded and otherwise deformed bedding. Disseminated pyrite, glauconites, and agglutinated benthic foraminifers are common. Fossil assemblages consist mostly of palynomorphs as well as agglutinated benthic foraminifers. A biostratigraphic revision, which is based on calcareous nannofossils, and planktonic and benthic foraminifers, as well as dinoflagellates (cf. Hull et al., this volume), suggests that the oldest sediments are of early Miocene age. The hole was abandoned because of the apparent shows of heavier hydrocarbons and because of the occurrence of strong, light yellow fluorescence in the lowermost cores.

\section{Sites 910,911 , and 912}

The three sites on the flank and top of Yermak Plateau were drilled to limited depth and, therefore, they have penetrated only Pliocene and Quaternary sediments. However, they contain the first true Arctic records of paleoceanographic changes during the latest part of the Cenozoic and are henceforth of major interest even though the Yermak Plateau sites have a very marginal location in the Arctic Ocean proper. The penetrated lithologies consist of firm, nearly homogeneous silty clays and clayey silts with sporadic calcareous nannofossils and planktonic foraminifers. The deposits are variably bioturbated and consist of homogeneous clayey silts and silty clays with minor layers of silty and clayey muds. Biogenic particles are rare. Slight to intense bioturbation is present throughout the sequences. Dropstones are common in most of the sediments, even though Sites 911 and 912 contain horizons where the dropstone frequency is considerably reduced. The dominant dropstone lithologies are siltstones, sandstones, and shales with minor quantities of coal fragments, plutonic rocks and limestones. Only at Site 912 do metamorphic and igneous rocks occur commonly as dropstones. The sediments are rich in terrigenous organic material throughout and produced large amounts of methane at several instances.

Site 910 is particularly interesting because it is located on the central portion of the inner Yermak Plateau in relatively shallow water. Various stiff and sticky sediments close to the surface inhibited the coring process and the lithology is distinguished from the other sites because it contains very firm, nearly homogeneous silty clays and clayey silts which are highly consolidated relatively close to the surface. These aspects are related to the impact of relatively old glacial ice covers (Flower, this volume) and may be related to ice resting on the Barents Shelf. This will be discussed further below (also cf. contributions by Flower, this volume and Rack et al., this volume).

The revised stratigraphic interpretation of the sites (Hull et al., this volume) has been applied to illustrate the distribution of the various sedimentary facies against time in Figure 4 . This will be discussed further below.

\section{Implications for the Tectonic and Volcanic History of the Norwegian-Greenland Sea, Paleoceanographic Aspects}

The two major gateways, the Greenland-Scotland Ridge and the Fram Strait, both play a major role in the deep-water exchange between the Arctic Ocean and the world oceans. The Leg 151 drill sites did not in any direct way address the evolution of the southern gateway (the Greenland-Scotland Ridge) in contrast to Leg 162. Therefore, here we refer only to the general knowledge of the evolution and subsidence of the Greenland-Scotland Ridge presented in the introduction (Thiede and Myhre, this volume). Leg 151, however, focused on the northern gateway by drilling two sites in Fram Strait and three on the Yermak Plateau.

The plate tectonic evolution of the northern Greenland Sea is not well understood but is based on geophysical data in the adjacent Arctic Ocean and Norwegian-Greenland Sea as well as on the two Leg 151 Fram Strait drill sites, Sites 908 and 909, integrated with various geophysical data. Myhre et al. (1995) suggest, in agreement with Lawver et al. (1990), that a deep-water connection between the Arctic Ocean and the Greenland Sea first developed during the late Miocene (cf. Kristoffersen, 1990). The southern part of the Greenland Sea opened during the Eocene, while compressional movements took place in the northern part. The onset of rifting in the northern part started at about $33 \mathrm{Ma}$ at the Eocene/Oligocene transition, and the rift phase probably lasted between 15 and18 m.y. before the Hovgård Ridge microcontinent finally rifted from the Svalbard Margin and before the onset of seafloor spreading between the microcontinent and the margin. The extent of the microcontinent also led Myhre et al. (1995) to suggest that much less oceanic crust exists in the northern Greenland Sea than earlier had been thought. A simplified reconstruction of the Hovgård microcontinent from its present-day position back to Anomaly 13 time (Myhre et al., 1995) shows that the rift phase included a major shear component during which the microcontinent moved northwestward oblique to the Svalbard Margin. Based on the extent of the major unconformity at Site 908 and on sedimentological, paleontological as well as palynological, and seismic data, various authors suggest an uplift of the ridge above sea level in the last rift phase and a subsidence of the microcontinent below sea level in the late Miocene-Pliocene. Furthermore, Myhre et al. (1995) suggested that the microcontinent acted as a plug in the southern part of the Fram Strait through at least early and middle Miocene, giving rise 
to the restricted basin circulation observed in the Miocene sediments, the lack of calcareous and biosiliceous fossils, and the large amount of agglutinated benthic foraminifers in Site 909.

The results of Leg 151 regarding the origin of the oceanic crust and of the volcanism occurring throughout the history of sedimentation in the Norwegian-Greenland Sea are of modest importance for the interpretation of the paleoceanographic history. Therefore, they will be dealt with only cursorily. The crystalline rocks found at the bottom of Hole 907A on the Iceland Plateau consist of tholeiitic basalts, and they display well-defined glassy rims that grade into vesicular rims and aphyric interiors, which suggests that pillow structures have been penetrated (Davis and McIntosh, this volume). Because of the smooth character of the oceanic "basement" reflector and the occurrence of deeper "intracrustal" reflectors, it is questionable whether this is true oceanic basement. The age obtained through ${ }^{40} \mathrm{Ar} /{ }^{39} \mathrm{Ar}$ dating of 13.2 Ma (obtained from ground-mass concentrates according to Davis and McIntosh (this volume) is considerably younger than the ages from magnetic Anomaly $6 \mathrm{~B}$, which according to Berggren et al. (1995) would have an age of 22 to $24 \mathrm{Ma}$. Henceforth, it is uncertain how much subsidence the site location has undergone since the extrusion of the basalts encountered in the deepest part of the hole. The site is located today in less than $2000 \mathrm{~m}$ of water and the water depth most certainly must have been much shallower during the time of eruption of these basalts.

The distribution of volcanic ash at Sites 907, 913, and 908 demonstrates the magmatic evolution of the late elements of the Norwegian-Greenland Sea volcanism, which occurred continuously since its early origin in the late Paleocene and early Eocene (Fig. 5). The most complete sequence of volcanic ash has been observed at Site 907 in Miocene to Quaternary deposits, while isolated occurrences of enigmatic source areas have been found in the Eocene-Oligocene sequences of Site 913 and in the Miocene-Pliocene of Site 908. The sequence of volcanic ash observed in Hole 907A (Werner et al., this volume; Lacasse et al., this volume) in general terms displays a very similar stratigraphic distribution to that found in the ODP Leg 104 sites on the Vøring Plateau (Bitschene et al., 1989). The ashes at Site 907 as well as those on the Vøring Plateau show a high concentration in the middle and upper Miocene sediment sections, with a well-developed decrease during the later part of the Pliocene and the Quaternary and with much less ash on the Vøring Plateau than over the Iceland Plateau. This may have to do with the increasing distance from the main source area which, based on the geochemical characteristics of these ashes, is inferred to be mainly Iceland (Bitschene et al., 1989; Werner et al., this volume). For a few ashes it has been assumed that volcanism on Jan Mayen may be the origin (Werner et al., this volume), but the young intraplate volcano Vesterisbanken (Cherkis et al., 1994) probably also has to be considered. Whether this applies to the volcanic ashes at Site 913 and 908 must remain open, and potential other sources have to be considered. Even though a general relationship between the frequency of ashes at Site 907 and the occurrence of siliceous microfossils (Thiede et al., 1995) can be seen in the various data, no clear paleoceanographic relation between the occurrence of such microfossils and of volcanic ashes could be defined at this stage. It may be only caused by well-known preservative effects; that is, siliceous microfossils in or close to volcanic ashes are much better preserved than those in ash-free sections).

\section{Sedimentological and Biostratigraphic Synthesis}

The sedimentary records obtained in the various drill sites and their lithologies have been cursorily described in the previous chapters. They have been placed into a framework of tectonic and volcanic events which led to the formation of the Norwegian-Greenland Sea, Fram Strait, and the Yermak Plateau (Arctic Ocean). We will now try to translate the drilling record into a temporal framework in an attempt to deduce trends and events of paleoceanographic and pa- leoclimatic history of the Norwegian-Greenland Sea (the gateway between the Arctic Ocean and the Norwegian-Greenland Sea and of the adjacent Arctic Ocean) including an attempt to make certain deductions on the paleoclimatic evolution on the surrounding land masses. This requires that we consider the revised stratigraphy of the drill sites because we have to arrange the observations at the various drill sites into a temporal framework (Fig. 4).

Based on numerous specialists' chapters and the preliminary observations contained in the Leg 151 Initial Reports volume (Myhre, Thiede, Firth, et al., 1995), Hull et al. (this volume) have established an integrated biostratigraphic framework for the various sites and have correlated the biostratigraphic framework to the geomagmatic polarity time scale (GPTS). For consistency's sake we have continued to use Cande and Kent (1992), which was available during Leg 151 , even though revisions have become available in the meantime (cf. Berggren et al., 1995). Hull et al. (this volume) have carefully screened the specialists' chapters prepared for the Scientific Results volume, as well as the preliminary results published in the Leg 151 Initial Reports, which already contain many details but are mainly based on core catchers and therefore could be considerably refined in the second stage of analysis. The biostratigraphic synthesis is based on eleven microfossil groups. For most of the sites, multiple biostratigraphic schemes, which had to be intercorrelated, have been established.

Remains of eleven biostratigraphically useful microfossil groups have been recovered from seven sites drilled during Leg 151. They include marine planktonic and benthic organisms, as well as terrestrial plant remains (pollen and spores). Hull et al. (this volume) analyzed the biostratigraphy of planktonic and benthic foraminifers, calcareous nannofossils, ostracodes, diatoms, radiolarians, silicoflagellates, ebridians, actiniscidians, dinoflagellates, and other palynomorphs, and established a composite biostratigraphy of each of the site. Using the GPTS of Cande and Kent (1992), they then correlated the biostratigraphy to the chronostratigraphic scheme. This revised stratigraphy has been applied to the drilled lithologic records (Fig. 2) to see how history of sedimentation of the Norwegian-Greenland Sea can be placed into a temporal framework (Fig. 4).

In this attempt Hull et al. (this volume) have encountered numerous problems, which are typical for a small and marginally located ocean basin such as the Norwegian-Greenland Sea. DSDP Leg 38 (Talwani, Udintsev et al., 1976) and ODP Leg 104 (Eldholm, Thiede, Taylor et al., 1989) had already established a chronostratigraphic framework for the deep-sea sediments of the Norwegian-Greenland Sea. This framework has been synthesized by Goll (1989), but it was clearly an early stage of refinement. The stratigraphy of the Norwegian-Greenland Sea Cenozoic sediment cores, and its problems are related to the endemic nature of many of the marine faunas and floras because of the restricted water exchange between the main basin of the North Atlantic Ocean and the Norwegian-Greenland Sea. Also, a number of the biostratigraphically useful microfossil groups, such as calcareous nannofossils, planktonic foraminifers, and radiolarians, had to adapt to a marginal and extreme habitat which was limited or severely restricted by the occurrence of the ice margin in this area. In addition, it is not quite clear from where these invading faunas and floras arrived in the Norwegian-Greenland Sea and when the opening between the Arctic Ocean and the Norwegian-Greenland Sea through Fram Strait was established (Kristoffersen, 1990; Eldholm et al., 1990).

Despite these problems, and by drawing on the previously cited data, Hull et al. (this volume) have been able to establish a timing for the history of sedimentation in the entire area and the biostratigraphic data presented in the Initial Reports (Myhre, Thiede, Firth, et al., 1995) have proven to be largely correct. Major changes, though, have been found at Site 908, where the lowermost part of the section below the unconformity (Myhre, Thiede, Firth et al., 1995) has been defined to contain only Oligocene sediments, and at Site 909 in the central 

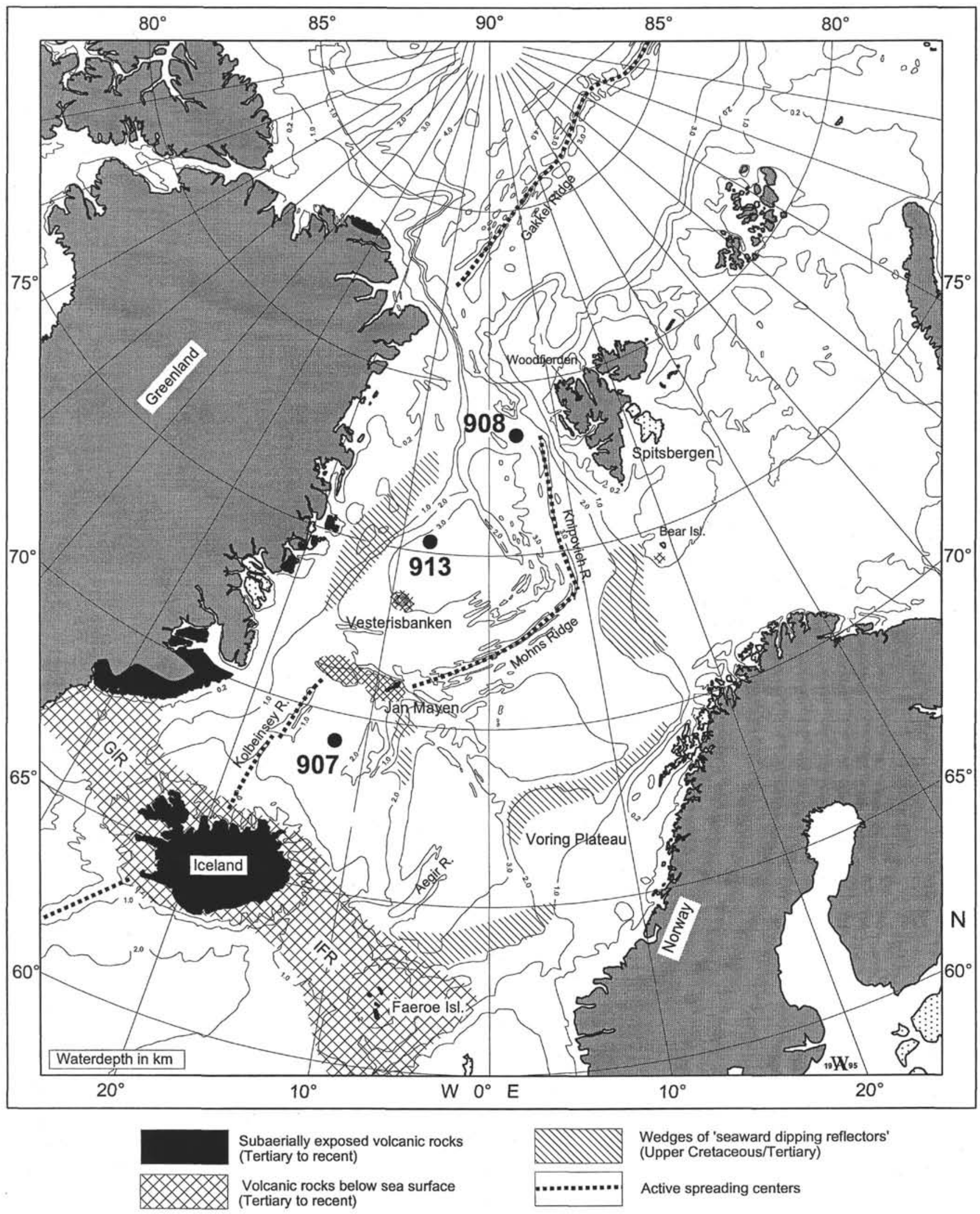

Figure 5. Locations of Sites 907, 908, and 913, and the generalized distribution of the Tertiary to Holocene volcanic activities in the North Atlantic Volcanic Province. Compiled from different sources (e.g., Mutter et al., 1988; Eldholm, 1991; Mørk and Duncan, 1993). GIR = Greenland Iceland Ridge, IFR = Iceland Faeroe Ridge (= Greenland- Scotland Ridge). From Werner et al., this volume. 
Fram Strait, which is now known to bottom out in Miocene deposits. Minor changes that led to the provision of a number of period and stage boundaries have been observed at Sites 910,911, and 913. No changes at all have been observed at Site 912 .

When placing the drilling records into the temporal framework, and when considering the results of Leg 151 as a whole (Fig. 4), it can be stated that this leg has successfully established the paleoceanographic history of the entire area for the time span since $50 \mathrm{Ma}$, with only small gaps in the Oligocene and Miocene.

It is particularly noteworthy that it has been possible to establish (1) the transitions from the early warm to temperate young Norwegian-Greenland Sea during the Eocene and Oligocene to the cool to cold preglacial Norwegian-Greenland Sea in late Oligocene and early to middle Miocene, (2) the onset and early glacial history of the area and of the surrounding continents, (3) the onset of and variability of major glaciation on the Northern Hemisphere on the continents around the Norwegian-Greenland Sea and in the adjacent Arctic Ocean, and (4) the glacial/interglacial changes during the middle and the late Quaternary. It is evident that many of the sites document very local conditions, namely the pelagic environments of the open southwestern Norwegian-Greenland Sea (Site 907, Iceland Plateau), the depositional environments close to the continental margins of East Greenland (Site 913), the history of sedimentation in the shallow and deep Fram Strait (Sites 908 and 909), and the depositional mode of the marginal Arctic Ocean under the influence of the late Neogene and Quaternary ice covers (Sites 910, 911, and 912).

Of the $3 \mathrm{~km}$ of drilled Leg 151 records, $75 \%$ belongs to the Neogene and Quaternary and, as in most other instances, the early stages of the history of this entire area are recorded only at one or a few drill sites. In particular, the warm and temperate young NorwegianGreenland Sea (during the Eocene and early Oligocene) has only been documented at Site 913, which represents a very special location and where the younger sediments are separated from this interval by an important hiatus. The cool to cold preglacial NorwegianGreenland Sea and Fram Strait are documented basically in three sites, namely the deep Fram Strait (Site 908 and 909) and the Iceland Plateau (Site 907), whereas glacial depositional environments documenting the early stages of glaciation and the variability of glacial/ interglacial changes have been encountered at all sites.

Much of the information obtained during Leg 151 was added to by Leg 162 (Jansen, Raymo, Blum, et al., 1996), and many of the interpretations will be refined when the scientific results of this leg will be published. Here, however, we will use the data from the Leg 151 sites to describe a number of chapters of trends and events of the paleoceanographic and climatic history of the area.

\section{Trends and Events in the Paleoceanographic and Climatic History of the Norwegian-Greenland Sea, Fram Strait, and the Marginal Arctic Ocean}

At the preliminary stage of investigations this final chapter of the scientific results of Leg 151 cannot be a comprehensive synthesis of the paleoceanographic history of the Norwegian-Greenland Sea nor of the northern gateway visited during this leg (Fig. 2). Rather, we will try to define a number of trends and events of the paleoceanographic interpretation of the results that can be deduced from the Leg 151 drill sites. We have to take into account changes in the properties of the surface, intermediate, and bottom waters of this ocean basin, the history and variability of the ice cover (both in terms of sea ice and iceberg input), the history of the ice sheets on the shelves and continents surrounding the Norwegian-Greenland Sea and adjacent to Fram Strait and the marginal Arctic Ocean, and the mode of water exchange between the North Atlantic Ocean and Norwegian-Greenland Sea, as well as between the Norwegian-Greenland Sea and the Arctic Ocean. Particularly interesting are prominent events or trends that led to the onset of Northern Hemisphere glaciation and to the in- tensification of the northwest European continental ice-sheet formation, including shedding large numbers of icebergs into the adjacent deep-sea basin, as well as the development of the system of glacial/ interglacial changes. While we have been rather successful in deciphering long-term trends, the short-term changes of the atmospheric and oceanic systems, which lately have been documented so successfully in the Greenland ice cores and in the North Atlantic high sedimentation rate deep-sea cores (Bond et al., 1993), cannot be analyzed in sufficient detail at the present stage of analysis in the Leg 151 cores.

\section{Early Eocene Greenland Basin Depositional Environments}

In the lowermost cores of Site 913, coarse-grained, poorly sorted, graded beds with large clay clasts and coal as well as lamination throughout have been observed. They suggest a rapidly deposited sediment due to gravity flows and the proximity of the depositional environment to the continent which is further amplified by the occurrence of near-shore marine assemblages of benthic foraminifers (Hull et al., this volume; Osterman, this volume). Because of the unknown nature of the basement under Site 913 it is rather difficult to determine paleodepths and depositional environments of these oldest sediments obtained during Leg 151. At this time it seems most likely that the coarse layers are displaced from the nearby continental margin and shelf of East Greenland into the narrow young Greenland Basin, which was fully marine and connected to the world ocean (Vogt et al., 1981).

\section{The Paleogene Warm and Fertile Norwegian-Greenland Sea}

During the middle and late Eocene (approximately 49 to $34 \mathrm{Ma}$ ) the Norwegian-Greenland Sea grew into an ocean basin of modest size (Vogt et al., 1981) with open connections to the world ocean. It developed highly fertile water masses, which are documented by rich siliceous microfossil assemblages (radiolarians, silicoflagellates, ebridians and organic-walled dinoflagellates, whereas diatoms seem to occur in relatively modest quantities only). The habitat of these pelagic microfossils must have been temperate to warm surface waters that were fertile, as indicated by siliceous faunas and floras (Hull, et al., this volume), by dinoflagellates and acritarchs (Firth, this volume), and by diatoms (Scherer and Koç, this volume). Blooms of these microfossils resulted in relatively fine-grained sediments and siliceous oozes intercalated into a sequence of fine-grained terrigenous sediments. The silicoflagellates seem to demonstrate that there was a considerable and permanent surface-water exchange between the Norwegian-Greenland Sea and the Arctic Ocean at that time.

It is much more difficult to interpret the properties of the bottomwater masses. However, these masses must have been oxygen deficient based on the laminations that are observed in parts of these sections, as well as on the occurrence of the agglutinated benthic foraminifers and the only moderately bioturbated parts of the section that were observed at Site 913 . The stratification and lamination of the sediments in several intervals are very accentuated because the sediments display lively colors with exciting shades of blue, purple, and green. This coincides with an increase in the preservation and abundance of siliceous microfossils and the development of discrete siliceous ooze intervals. As a result of relatively high organic carbon contents and high productivity, no calcareous microfossils have been preserved from this interval because all calcareous material has dissolved.

\section{Adaptation of Marine Planktonic Floras and Faunas}

The history of the Norwegian-Greenland Sea and Arctic Ocean provides some of the best data for evaluating the processes of adaptation of the pelagic biota to rapidly changing life habitats. All indi- 
cations are that the Arctic Ocean and the Norwegian-Greenland Sea have been fully marine during roughly the past $50 \mathrm{Ma}$, with temperature being the major biotic control that responded to the paleoclimatic changes of the middle and late Cenozoic in the area. However, as documented by most of the pelagic faunas and floras (see various specialists' chapters), there are major changes in the composition of the groups contributing to the pelagic biota, making it almost impossible to choose one or two of the major pelagic microfossil groups to trace this evolution. Only dinoflagellates occur continuously from the early Paleogene throughout the entire Neogene/Quaternary in the area. The lower Paleogene dinoflagellate cyst and acritarch assemblages that were recovered in the upper/middle Eocene to Oligocene section of Hole 913B off northeast Greenland revealed important fluctuations in the dominance between peridinoid and gonyaulacoid cysts throughout (Firth, this volume). Two peaks in peridinoid dominance seem to coincide with events of high paleoproductivity which resulted in the deposition of biosiliceous-diatom- and radiolarianrich-oozes. In the lower and middle Neogene part of the sections of Sites 907, 908, and 909 land-derived palynomorphs and plant debris are increasingly important (Poulsen et al., this volume). According to a specialist's study (Poulsen et al., this volume) the dinoflagellates of Site 907 Miocene deposits suggest that oceanic conditions were warmer than today but that nutrient concentrations were relatively low. Finally, the Pliocene and Quaternary sediments (Matthiessen and Brenner, this volume) also contain sufficient dinoflagellate cysts to establish a biostratigraphic frame. The composition of the various assemblages changes considerably between the presence of subpolar to cold temperate surface waters. The distinct succession of assemblages in the Pliocene and Quaternary sediments of Site 911 (Yermak Plateau, cf. Matthiessen and Brenner, this volume) allow us to establish a clear ecostratigraphic zonation, the boundaries between the various entities revealing major paleoceanographic events in the eastern Arctic Ocean. The ecology of many of the dinoflagellate cysts is not well known, and their study and paleoceanographic interpretations are further complicated because of the important amounts of reworking observed in many of the Leg 151 cores, indicated by the occurrence of Cretaceous and lower Tertiary palynomorphs in younger parts of the section.

\section{The Change from a "Siliceous" to a "Calcareous" Norwegian- Greenland Sea and Arctic Ocean}

The composition of the biogenic components derived from pelagic organisms has gone through a systematic and very important change over time both in the Norwegian-Greenland Sea and in the Arctic Ocean. The scarce sample coverage in the Arctic Ocean of upper Mesozoic and Paleogene sediments (Thiede et al., 1990) as well as the available ODP and DSDP drill sites in the Norwegian-Greenland Sea, reveal that except for few and isolated occurrences, the pelagic biota are dominated by siliceous microfossils in the entire $\mathrm{Pa}$ leogene part of the sedimentary record. In the early Neogene parts of the stratigraphic section that were not flooded by terrigenous finegrained material, siliceous microfossils dominate, whereas the occurrences of calcareous pelagic microfossils are exceptions. During the Paleogene, radiolarians and silicoflagellates sometimes occur together with diatoms. During the later part of the Miocene and early Pliocene, remains of diatom floras dominate the sedimentary sections. As documented by Baumann et al. (this volume), the calcareous nannoplankton and planktonic foraminifers at Site 644 are confined to the middle/upper Pliocene and Quaternary, with an important increase observed which occurred only during the last million years. The same applies to isolated occurrences of calcareous nannofossils (coccoliths). As compared to the Leg 151 sites (in particular, the pelagic Site 907 on the Iceland Plateau), it is obvious that this development occurs almost simultaneously or only slightly later.
The dissolution index established by Henrich (1986) and used by Baumann et al. (this volume) suggests that dissolution reduced the role of calcareous microfossils in the early part of the studied records. Their preservation was possible only during the latest part of the history of the Norwegian-Greenland Sea. One of the reasons for drilling Site 907 and establishing a transect across water depth was the attempt to establish the history of carbonate preservation throughout the Neogene and Quaternary. Now such studies have to be restricted to the last million years and one has to accept that prior to $1 \mathrm{Ma}$ the Norwegian-Greenland Sea and the Arctic Ocean was primarily a "siliceous" ocean, whereas the switch to a "calcareous" ocean along with the preservation of calcareous pelagic microfossils only occurred at approximately $1 \mathrm{Ma}$. Patterns of the switch have been discussed at various studies (cf. Bohrmann et al., 1990). As suggested by the studies this shift probably already occurred during the early Pliocene, and it is only an effect of the much better carbonate preservation from approximately $1 \mathrm{Ma}$ on, which seems to be related to the much stronger advection of Atlantic waters during the glacial/interglacial periods. This change of the dominant biogenic components represents one of the major paleoceanographic enigmas of the Northern Hemisphere deep-sea basins.

\section{Onset and Variability of Calcareous Pelagic Microfossil Sedimen- tation in the Norwegian-Greenland Sea and in the Arctic Ocean}

Calcareous material has been deposited in the Norwegian-Greenland Sea during the later part of the Pliocene and the entire Quaternary (Baumann et al., this volume). The calcareous material consists of redeposited carbonates from the surrounding land masses (mainly as ice-rafted material) and the remains of pelagic microfossils in particular, calcareous nannofossils and planktonic foraminifers. After modest and spotty occurrences during the time span between $3 \mathrm{Ma}$ and $1 \mathrm{Ma}$, they consistently appeared from $1 \mathrm{Ma}$ to modern times over the Vøring Plateau, as repeatedly demonstrated by the detailed study of the occurrence and preservation by Henrich and Baumann (1994) (cf. Baumann et al., this volume). Prior to $1 \mathrm{Ma}$, the dissolution of planktonic foraminifers is so strong (very high dissolution indices according to Henrich and Baumann [1994]), that one has to assume the dissolution of most of the calcareous material.

During the past million years at ODP Site 644 the occurrences of planktonic microfossils and of dissolution reveal a clear pattern in that the frequencies of planktonic foraminifers and coccoliths display a cyclicity with very high abundances during times when the Norwegian Current is present in the eastern Norwegian-Greenland Sea and in intervals where abundances are low. During times of diamicton formation large proportions of organic carbon were preserved, which led to an important intensification of the carbonate dissolution and, therefore, to poor preservation of the calcareous faunas and floras. This pattern is modified in the western Norwegian-Greenland Sea (in particular, according to the data from Site 907 [Iceland Plateau] and Site 909 [Fram Strait], where carbonate concentrations are lower than over the Vøring Plateau and where apparently the onset of the intensification of carbonate sedimentation occurs a bit later than in the eastern Norwegian-Greenland Sea. The data from Sites 907 and 909 , even though stratigraphically not as well confined as at Site 644, display a similar type of variability in frequencies of occurrence of the major pelagic microfossils and henceforth they can also be related to the intensity of the surface-water influx from the North Atlantic Ocean. This is easily explained and accepted for the eastern part of the Norwegian-Greenland Sea, where the Norwegian Current is channeling the waters of the North Atlantic Drift to the north (also into Fram Strait) but it is not easily explained for the Iceland Plateau site. It is interesting to note that in general terms the occurrence of calcareous benthic foraminifers in the sediments follows a pattern similar to those of the pelagic microfossil (calcareous nannofossils and planktonic foraminifers), suggesting isochronous pulsations of 
the entire biotic system of the Norwegian-Greenland Sea (Struck, 1995). Particularly warm events are usually accentuated by the occurrence of subpolar planktonic foraminifers, which is accentuated by the influx of North Atlantic waters.

\section{Evolution of Terrestrial Floras During the Late Cenozoic of Both Sides of the Norwegian-Greenland Sea}

Some of the Leg 151 drill sites are flooded by pollen and spores, reflecting important aspects of the biogeography and temporal changes of the terrestrial floras on both sides of the NorwegianGreenland Sea. Manum (1976) actually quantified the relationship between the marine dinoflagellate cyst occurrences with those of terrestrial plant debris, including pollen and spores and was able to subdivide the history of the Norwegian-Greenland Sea depositional environment into a number of phases of variable dominances of both types of palynomorphs. The data of Leg 151 allow us to further define this picture, in particular for the Hovgård Ridge (Site 908), where large quantities of terrestrial plant remains have been found. The Oligocene floras of the Hovgård Ridge sediments below the unconformity (Myhre, Thiede, Firth, et al., 1995) provide a new insight into previously unknown or poorly known high northern latitude terrestrial vegetation. Based on their frequency, preservation and the palynobathymetric reconstruction of Hovgård Ridge (Myhre et al., 1995), a source area in very close neighborhood can be assumed. The pollen reflects forests of conifers with some angiosperms (Bolter and Manum, this volume) which were impoverished with respect to angiosperms as compared to the Paleocene and Eocene floras on Svalbard. As compared to the late Miocene times there seems to be little or no change in the composition of the floras.

The observations related to the pollen assemblages are supplemented by the studies of the Pliocene-Pleistocene deposits for the Yermak Plateau (Sites 910 and 911; Willard, this volume). The pollen of the Yermak Plateau upper Pliocene sediments documents terrestrial floras of boreal to subarctic climatic conditions in the vegetated area. Pinus is typical for the upper Pliocene pollen assemblages, with Picea and Betula as lesser components. The occurrence of these relatively warm floras will be discussed further below in comparison to some of the pelagic microfossil data. The Pleistocene assemblages (Site 911; Willard, this volume) are composed mainly of Pinus and Picea pollen, which suggests cold climates that are probably comparable to today. In addition, reworked palynomorphs have been found in variable quantities, obviously from a diversity of source regions that will not be discussed here in any detail because they are of little relevance for the paleoceanographic interpretation beyond the question of ice rafting, which can be addressed better using other components.

\section{The Late Pliocene Warm Event}

One of the major paleoclimatically significant recent observations is the data from Northeast Greenland, where Funder et al. (1985) found evidence for a warming episode intercalated into glacial sequences. The sediments of the Kap København Formation on Perry Land in North Greenland seemed to belong to the transitional interval of the Pliocene to the Pleistocene, but they contained frequently wellpreserved remains of terrestrial vegetation and invertebrate faunas indicative of a forest tundra environment (potentially comparable to present conditions in Labrador, according to Funder et al., 1985). The marine deposits hitherto did not provide a similar record until Leg 151 drilled in Fram Strait and on Yermak Plateau. Although not detected in the shipboard scientific investigations, which are dominantly based on core-catcher studies, Spiegler (this volume) and Osterman (this volume) conducted very detailed stratigraphic studies that detected evidence at Site 910 suggesting the presence of relatively warm surface waters in Fram Strait and on the Yermak Plateau. Even though this site has considerable stratigraphic problems, samples in Core 151-910D-10X contain a fauna which comprised inter alia Neogloboquadrina pachyderma dextral, Globigerinoides trilobus, and Turborotalia quinqueloba. In Cores 151-910D-13X and 14X of the same site the planktonic foraminifer Globigerinella aequilateralis has been detected. Finally, distinct warmer assemblages of planktonic foraminifers in Cores 151-910D-15X and 16X of Site 910D comprised species such as Menardella menardii, M. limbata, Neogloboquadrina dutertrei, Globoquadrina altispira, Globigerinoides ruber, Gl. conglobatus, Gl. extremus, and Gl. trilobus, most of which are typical for subtropical surface-water temperatures. The interval between Cores $10 \mathrm{X}$ and $15 \mathrm{X}$ was barren of planktonic foraminifers, except for the occurrence of Globigerinella aequilateralis. According to Spiegler these intervals are found in sequences that contain icerafted Inoceramus prisms and assemblages of cold-water benthic foraminifers (however, cf. Osterman, this volume). She has therefore suggested that warm and subtropical surface-water masses invaded during short-lived episodic events the generally cold NorwegianGreenland Sea and Arctic Ocean during the late Pliocene. The evidence provided by foraminifers is also supported by ostracodes (Cronin and Whatley, this volume).

Up to now it has been impossible to correlate in detail the Kap København Formation and the stratigraphy of Site 910 on Yermak Plateau; however, if a stratigraphic correlation for these two sections can be established, a major late Pliocene warming event affecting a wide area in the Arctic Ocean, and in particular the deep passage into the Arctic Ocean and the Norwegian-Greenland Sea, has been confirmed. At present it is not clear how and from where these warm surface waters invaded the Fram Strait. It will be an important task to test the relevant stratigraphic intervals of the other ODP and DSDP sites to see if comparable records can be found.

\section{Ice-Rafting and the Initiation of Northern Hemisphere Glaciation}

Large quantities of ice-rafted material have been found at all drill sites. The earliest occurrences of the ice-rafted material, and, therefore, the onset of Northern Hemisphere glaciation, remain a very enigmatic problem. Wolf-Welling et al. (this volume) studied in detail the coarse-fraction components of Sites 908 and 909 in an attempt to use grain-size distributions and coarse component compositions to establish the onset and variability of the early stages of glaciation. They found evidence for ice-rafting in the area as early as $14 \mathrm{Ma}$ (middle Miocene) and indications for substantial ice-rafting events at 10.8-8.6 Ma, 7.2-6.8 Ma, 6.3-5.5 Ma, and since 5 Ma. These data coincide with recent observations of Jansen and Sjøholm (1991), which suggested very early ice-rafting in the Vøring Plateau sites. Early records of ice-rafting and the transition from the preglacial intervals (with no ice-rafting) to the glacial intervals (with ice-rafting) have been found at Sites 907, 909, and 913. Because of the presence of the large hiatus, evidence from Site 908 on Hovgård Ridge remains problematic, and because the three sites from Yermak Plateau (Sites 910,911 , and 912) are relatively short in stratigraphic terms, the question of the earliest onset of glaciation at these locations remains unresolved. Data from the upper part of Site 913 off East Greenland are deficient because of the poor recovery record and because of the nature of the stratigraphic intervals that are represented in the wash core on top of the undisturbed Paleogene sediment sequence. However, despite the stratigraphic revisions and disputed evidence from the Vøring Plateau and Fram Strait, the impression remains that the first coarse ice-rafted material appears earliest off southern Greenland (with a probable Greenland source) and in the sediments of Site 907 (cf. also data from ODP Leg 152; Larsen, Saunders, Clift, et al., 1994) and that widespread ice-rafting developed during the late Miocene, whereas intensive ice-rafting with coarse components $(>1 \mathrm{~cm}$ 
in diameter) began later in the Fram Strait/Yermak Plateau area (probably during the latest Miocene and in the Pliocene; $\mathrm{cf}$. Thiede et al., 1995).

\section{The Source Regions for Ice-Rafted Detritus and the History of Terrestrial Glaciations on Greenland and in Eurasia}

Important quantities of dropstones have been found at all seven localities of Leg 151. The lithology of the individual dropstone assemblages, as well as the temporal variability of their fluxes, is different from locality to locality, reflecting local peculiarities of the source region of the icebergs carrying the ice-rafted material and of the depositional site. The dropstones at Site 907 do not occur very frequently. The largest component, $>1 \mathrm{~cm}$ in diameter, has been found in Core 908A-13X of earliest late Miocene age. The lithologies of the coarse IRD comprise basalts (Icelandic source?), quartz, gneisses, siltstones and sandstones. Intensification of ice-rafting at this site has been observed at the bottom of Core $7 \mathrm{H}$ upward, corresponding to a Pliocene age of approximately $4 \mathrm{Ma}$. At Site 908 large dropstones have been observed in sediments younger than $5 \mathrm{Ma}$, and a phase of intensification of ice-rafting can be observed in Cores 151$908 \mathrm{~A}-9 \mathrm{H}$ and $10 \mathrm{H}$ which belongs to the middle Pliocene. Site 909 in the deep Fram Strait comprised a long and stratigraphically more or less complete section, covering the transition of the preglacial to the glacial environments. The oldest large dropstone has been observed in Pliocene sediments (Core 151-909C-16R) which also belong in the middle Pliocene. A phase of intensification is not as clearly developed as in the two previous sites, but can potentially be found in the interval that belongs to the upper Pliocene (Cores 151-909C-5R to 9R; the stratigraphic boundary between Pliocene and Quaternary deposits is not quite clear at this site (cf. Hull et al., this volume). As at Site 908 the coarse ice-rafted dropstones $(>1 \mathrm{~cm}$ in diameter) are dominantly sedimentary rocks with a wide variety of different lithologies, whereas crystalline rocks such as granodiorites, gabbro(?), and basaltic material(?) have only very rarely been observed. Site 910 on the shallowest part of the Yermak Plateau displays a very similar pattern. Large dropstones have been found in modest quantities throughout the entire $500 \mathrm{~m}$ of the sedimentary column penetrated at this site, but an important increase in large dropstones is observed only in the upper Pliocene part of the section (Core 151-910C-24R). As for Sites 908 and 909 , the composition of the large dropstones is mainly sedimentary rocks. A similar picture developed for Site 911, where the increase in dropstone frequencies has been observed in middle Pliocene sediments of approximately 2.7 to $2.8 \mathrm{Ma}$. Dropstone frequencies upsection are highly variable and will have to be analyzed in detail once better stratigraphic ages are available. Sedimentary lithologies, including coal, are typical for the dropstone assemblage in this site, too. At Site 912, the important increase in dropstone frequencies is observed possibly in Quaternary sediments (in an interval between NN19 and NN18/19, cf. Hull et al., this volume). Lithologies are again dominated by sedimentary rocks.

At Site 913, the record of ice-rafting could not be resolved in its temporal pattern because of the very poor core recovery of the uppermost $400 \mathrm{~m}$ of the cored section. However, it is clear from the large proportions of gneiss and crystalline rocks that a different source region (probably in Greenland) has to be considered.

\section{The Extension of the Svalbard Ice Sheet over the Yermak Plateau}

The three Yermak Plateau sites have sampled locations in relatively shallow water depths. The detection of an overconsolidated interval at Site 910, which is located closest to Svalbard, and the absence of such an overconsolidated interval at Sites 911 and 912, offer an opportunity to consider the extent of the Svalbard ice sheet to the north (if the overconsolidated zone can be related to the load of an ice sheet). A number of specialists' studies have tried to consider the characteristics of this site which penetrated $500 \mathrm{~m}$ of a sedimentary section of late Pliocene and Quaternary age and obviously documents a depositional environment under glacial influence (however, compare the description of the Pliocene warm event). Flower (this volume) has established the Quaternary stable isotope stratigraphy of this site in considerable detail and tried to relate the depositional history to the history of the Svalbard ice sheet and its extension toward the north. If the isotope records are properly interpreted (Flower, this volume), the overconsolidated section is older than oxygen isotope stage 17 (approximately $700 \mathrm{ka}$ ). It is not evident, either from the physical properties or from bio- or isotope-stratigraphic data, whether a hiatus separates the overconsolidated section from the more or less complete stratigraphy of the overlying $\sim 19$-m-thick section. If the stratigraphic interpretation is correct, the overconsolidated section documents the latest extension of the Svalbard ice sheet approximately $100 \mathrm{~km}$ to the north of Svalbard over the Yermak Plateau. The undisturbed stratigraphy of the overlying part of the section has to be interpreted that the Svalbard ice sheet never extended farther across the shelf and adjacent part of Yermak Plateau than during oxygen isotope stage 18. Cores from the Arctic Ocean seem to suggest that at approximately the same time the first evidence for a major extension of the Eurasian ice sheets could be observed (Spielhagen et al., unpubl. data). Further refinement of the stratigraphic data and of the drilling record of Site 910 will be needed to further evaluate the data of this site (Rack et al., this volume).

\section{Paleoceanographic Variability of the Norwegian-Greenland Sea, Fram Strait, and the Adjacent Arctic Ocean During the Neogene and Quaternary}

The incomplete stratigraphic evaluation of the Leg 151 drill sites make it difficult to evaluate their records for patterns of systematic variability and cyclicities in the time scales of the Milankovitch frequencies. However, a number of data sets allow us to state that the oceanic records at least at times seem to record such cyclicities (cf. Rack et al., this volume). Such data sets of systematic variability can mainly be deduced from the occurrence of calcareous plankton in the Norwegian-Greenland Sea, from the stable light isotope records where enough calcareous material has been preserved, and from some of the physical properties that have been measured through a variety of tools (multisensor track data, physical properties, magnetostratigraphy, logging, cf. Rack et al,, this volume) during the leg. Early indications of such periodicities were provided by the Site 907 data. Physical properties such as density data (GRAPE) seem to suggest the presence of a frequency element related to obliquity in the lower Quaternary part of the penetrated section, whereas the record of magnetic susceptibility for the middle Pliocene part of the section revealed the presence of 100-, 41-, 23-, and 19-k.y. periodicities. The same periodicities were encountered in the upper/lower and lower/ upper Oligocene sediments of Site 908. At Site 911, preliminary spectral analysis of the deep phasor induction log over the interval 110 to 240 mbsf showed much spectral power in the log occurring at the 40- and 100-k.y. bands, concurring with known Milankovitch frequencies.

Well-developed periodicities have also been observed in the stable oxygen isotope data of planktonic foraminifers from Site 907 (Fronval and Jansen, this volume) and of the young records of the Fram Strait and Yermak Plateau sites. Data sets of Hevrøy et al. (this volume) and of Flower (this volume) show encouraging results of very regular shifts of the planktonic oxygen isotope data, which can be used to establish a precise stratigraphy for the past 600,000 to $700,000 \mathrm{yr}$, and which potentially will allow us to systematically investigate regularities and irregularities of the paleoceanographic changes at the time scales of the Milankovitch frequencies. 


\section{ACKNOWLEDGMENTS}

It would not have been possible to establish this paleoceanographic history of the North Atlantic-Arctic Gateway without drawing on the large number of specialized studies provided by the shipboard and shore-based scientists. We again were helped by numerous students and various technical assistance. Leg 151 led to a number of very fruitful scientific contacts and we would like to express our gratitude to the entire shipboard scientific party, as well as to the shore-based scientific party, for their important input into studying the paleoenvironments of the Norwegian-Greenland Sea.

\section{REFERENCES}

Berggren, W.A., Kent, D.V., Swisher, C.C., III, and Aubry, M.-P., 1995. A revised Cenozoic geochronology and chronostratigraphy. In Berggren, W.A., Kent, D.V., Aubry, M.-P., and Hardenbol, J. (Eds.), Geochronology, Time Scales and Global Stratigraphic Correlation. Spec. Publ.Soc. Econ. Paleontol. Mineral., 54:129-212.

Bitschene, P.R., Schmincke, H.-U., and Viereck, L., 1989. Cenozoic ash layers on the Vøring Plateau (ODP Leg 104). In Eldholm, O., Thiede, J., Taylor, E., et al., Proc. ODP, Sci. Results, 104: College Station, TX (Ocean Drilling Program), 357-366.

Bohrmann, G., Henrich, R., and Thiede, J., 1990. Miocene to Quaternary paleoceanography in the northern North Atlantic: variability in changes in carbonate and biogenic opal accumulation. In Bleil, U., and Thiede, J. (Eds.), Geological History of the Polar Oceans: Arctic versus Antarctic. NATO ASI Ser. C, 647-675.

Bond, G., Broecker, W., Johnsen, S., McManus, J., Labeyrie, L., Jouzel, J., and Bonani, G., 1993. Correlations between climate records from the North Atlantic sediments and Greenland ice. Nature, 365:143-147.

Cande, S.C., and Kent, D.V., 1992. A new geomagnetic polarity time scale for the Late Cretaceous and Cenozoic. J. Geophys. Res., 97:1391713951.

Cherkis, N.Z., Steinmetz, S., Schreiber, R., Thiede, J., and Theiner, J., 1994. Vesteris Seamount: an enigma in the Greenland Basin. Mar. Geophys. Res., 16:287-301.

Eldholm, O., 1991. Magmatic-tectonic evolution of a volcanic rifted margin. Mar. Geol., 102:43-61.

Eldholm, O., Skogseid, J., Sundvor, E., and Myhre, A.M., 1990. The Norwegian-Greenland Sea. In Grantz, A., Johnson, L., and Sweeney, J.L. (Eds.), The Arctic Ocean Region. Geol. Soc. Am., Geol. of North Am. Ser., L:351-364.

Eldholm, O., Thiede, J., Taylor, E., et al., 1987. Proc. ODP, Init. Repts., 104: College Station, TX (Ocean Drilling Program).

- 1989. Proc. ODP, Sci. Results, 104: College Station, TX (Ocean Drilling Program).

Funder, S., Abrahamsen, N., Bennike, O., and Feyling-Hanssen, R.W., 1985. Forested Arctic: evidence from North Greenland. Geology, 13:542-546.

Goll, R.M., 1989. A synthesis of Norwegian Sea biostratigraphies: ODP Leg 104 on the Vøring Plateau. In Eldholm, O., Thiede, J., Taylor, E., et al., Proc. ODP, Sci. Results, 104: College Station, TX (Ocean Drilling Program), 777-826.

Henrich, R., 1986. A calcite dissolution pulse in the Norwegian-Greenland Sea during the last deglaciation. Geol. Rundsch., 75:805-827.

Henrich, R., and Baumann, K.H. 1994. Evolution of the Norwegian Current and the Scandinavian Ice Sheets during the past 2.6 m.y.: evidence from ODP Leg 104 biogenic carbonate and terrigenous records. Palaeogeogr., Palaeoclimatol., Palaeoecol, 108:75-94.

Jansen, E., Raymo, M.E., Blum, P., et al., 1996. Proc. ODP, Init. Repts. 162: College Station, TX (Ocean Drilling Program).
Jansen, E., and Sjøholm, J., 1991. Reconstruction of glaciation over the past $6 \mathrm{Myr}$ from ice-borne deposits in the Norwegian Sea. Nature, 349:600603.

Kristoffersen, Y., 1990. Eurasian Basin. In Grantz, A., Johnson, L., and Sweeney, J.L. (Eds.) The Arctic Ocean Region. Geol. Soc. Am., Geol. of North Am. Ser., L:365-378.

Larsen, H.C., Saunders, A.D., Clift, P.D., and the Shipboard Scientific Party, 1994. Introduction: Breakup of the Southeast Greenland Margin and the formation of the Irminger Basin: background and scientific objectives. In Larsen, H.C., Saunders, A.D., Clift, P.D., et al., Proc. ODP, Init. Repts., 152: College Station, TX (Ocean Drilling Program), 5-16.

Lawver, L.A., Müller, R.D., Srivastava, S.P., and Roest, W., 1990. The opening of the Arctic Ocean. In Bleil, U., and Thiede, J. (Eds.), Geological History of the Polar Oceans: Arctic versus Antarctic: Dordrecht (Kluwer Academic Publ.), 29-62.

Manum, S.B., 1976. Dinocysts in Tertiary Norwegian-Greenland Sea sediments (Deep Sea Drilling Project Leg 38), with observations on palynomorphs and palynodebris in relation to environment. In Talwani, M. Udintsev, G., et al., Init. Repts. DSDP, 38: Washington (U.S. Govt. Printing Office), 897-919.

Mørk, M.B.E., and Duncan, R.A., 1993. Late Pliocene basaltic volcanism on the Western Barents Shelf margin: implications from petrology and ${ }^{40} \mathrm{Ar}-$ ${ }^{39} \mathrm{Ar}$ dating of volcaniclastic debris from a shallow drill core. Nor. Geol. Tidsskr., 73: 209-225.

Mutter, J.C., Buck, W.R., and Zehnder, C.M., 1988. Convective partial melting, 1. A model for the formation of thick basaltic sequences during the initiation of spreading. J. Geophys. Res., 93:1031-1048.

Myhre, A.M., Skogseid, J., Karlberg, T., and Eldholm, O., 1995. Tectonic evolution of Fram Strait Gateway in view of ODP Leg 151 results. 5th Inter. Conf. Paleoceanogr. (Abstract)

Myhre, A.M., and Thiede, J., 1995. North Atlantic Arctic Gateways. In Myhre, A.M., Thiede, J., Firth, J.V., et al., Proc. ODP, Init. Repts., 151: College Station, TX (Ocean Drilling Program), 5-26.

Myhre, A.M., Thiede, J., Firth, J.V., et al., 1995. Proc. ODP, Init. Repts., 151: College Station, TX (Ocean Drilling Program).

Struck, U., 1995. Stepwise postglacial migration of benthic foraminifera into the abyssal northeastern Norwegian Sea. Mar. Micropaleontol., 26:207213.

Talwani, M., Udintsev, G., et al., 1976. Init. Repts. DSDP, 38: Washington (U.S. Govt. Printing Office).

Thiede, J., Clark, D.L., and Herman, Y., 1990. Late Mesozoic and Cenozoic paleoceanography of the northern polar oceans. In Grantz, A., Johnson, L., and Sweeney, J.F. (Eds.), The Arctic Ocean Region. Geol. Soc. Am., Geol. of North Am. Ser., L:427-458.

Thiede, J., Myhre, A.M., Firth, J.V., and the Shipboard Scientific Party, 1995. Cenozoic Northern Hemisphere polar and subpolar ocean paleoenvironments (Summary of ODP Leg 151 drilling results). In Myhre, A.M., Thiede, J., Firth, J.V., et al., Proc. ODP, Init. Repts., 151: College Station, TX (Ocean Drilling Program), 397-420.

Vogt, P.R., Perry, R.K., Feden, R.H., Fleming, H.S. and Cherkis, N.Z., 1981. The Greenland-Norwegian Sea and Iceland environment: Geology and Geophysics. In Nairn, A.E.M., Churkin, M., and Stehli, F.G. (Eds.): The Oceans Basins and Margins (Vol. 5), The Arctic Ocean: New York (Plenum), 493-598.

Date of initial receipt: 7 March 1996

Date of acceptance: 31 May 1996

Ms 151SR-147 